\section{A tárolási feltételek hatása a kukorica Fusarium fertőzöttségére és toxin szennyezettségére}

\author{
Veres Edina ${ }^{1}$ - Borbély Mária ${ }^{2}$ - Győri Zoltán ${ }^{2}$ - \\ Kátai János ${ }^{1}$ \\ Debreceni Egyetem Agrártudományi Centrum, \\ Mezőgazdaságtudományi Kar, \\ ${ }^{1}$ Talajtani és Mikrobiológiai Tanszék, Debrecen \\ ${ }^{2}$ Mezőgazdasági Termékfeldolgozás és Minősítés Tanszék, \\ Debrecen
}

\section{ÖSSZEFOGLALÁS}

1997, 1998 és 1999-ben különbözö talajtipusokról betakaritott kukoricamintákat tároltunk hat hónapon keresztül eltérö feltételek (hömérséklet, nedvességtartalom, szemek állapota) mellett. Betakaritáskor, valamint a tárolás harmadik és hatodik hónapjában lemezöntéses eljárással meghatároztuk a minták Fusarium fertőzöttségét, illetve HPLC alkalmazásával mértük az F-2, T-2, HT-2, DON és DAS toxinok mennyiségét. Dolgozatunkban arra kerestük a választ, hogy az ökológiai tényezök, valamint a tárolási körülmények mennyiben befolyásolják a vizsgált paramétereket, illetve hatásuk statisztikailag igazolható-e. Közvetlenül a betakaritást követōen elvégzett vizsgálatok alapján megállapithatjuk, hogy a talaj típusa nem befolyásolta a vizsgált paramétereket. Az évjárat hatását elemezve azonban jelentős különbségeket tapasztaltunk. A kukoricaminták Fusarium fertözöttsége 1998-ban, mig toxinszennyezettsége 1999-ben volt a legnagyobb. A tárolási kisérlet eredményei azt mutatják, hogy a vizsgált paraméterekre szignifikáns hatást leginkább az évjárat (mikroszkopikus gombaszám, F-2, T-2, HT-2, DAS és összes toxin tartalom) és a szemek nedvességtartalma (F-2, T-2, és összes toxin tartalom) gyakorolt. A hömérséklet befolyásoló szerepe a T-2 toxin (eredeti nedvességtartalmú minták) és a DON toxin (14\% nedvességtartalmú minták) esetében nyert bizonyitást. Magasabb hömérsékleten való tárolás mellett nagyobb értékeket kaptunk. Az, hogy a szemek sérülései növelik a vizsgált paraméterek értékét a nem nedvesitett mintákban a DON koncentráció esetében, a nedvesitett mintáknál pedig a mikroszkopikus gombák számában igazoltuk.

\section{SUMMARY}

Corn samples harvested in 1997, 1998 and 1999 from different soil types were stored at different conditions (temperature, moisture content, state of kernels) for six months. The Fusarium contamination was examined by plate dilution method and the amount of mycotoxins (F-2, T-2, HT-2, DON, $D A S)$ were determined applying HPLC method immediately after harvesting and in the third and sixth month of storage. The aim of our study was to find correlation between the ecological factors, storage conditions and the examined parameters mentioned above, as well as to prove them statistically. According to the examinations carried out after harvesting we could state that the soil type had no effect on the parameters. Analysing the effect of the years we found considerable differences. The Fusarium infection of corn samples in 1998, while the toxin contamination in 1999 was the highest. The results of storage experiment show that year number of microscopic fungi, F-2, T-2, HT-2, DAS and total toxin content) and moisture content of kernels (F-2, T-2, and total toxin content) have a significant effect on the examined parameters. We could prove the effect of temperature on the T-2 content (samples with natural moisture content) and DON content (samples with $14 \%$ moisture content). Higher values were found at higher temperature storage. The ratio of damaged kernels influenced the DON concentration in the non-wetted samples and the number of microscopic fungi in the wetted samples.

\section{BEVEZETÉS}

A gabonafélék és a kukorica szemtermésének a minőségét - amely jelentősen befolyásolja élelmezési és takarmányozási célra, valamint vetőmagként való felhasználásukat - elsősorban a különböző nemzetségekbe (Alternaria, Aspergillus, Fusarium) tartozó penészgombák veszélyeztetik (Chelkowski, 1991; cit. Szécsi et al., 1998). Ezek a mikroszkopikus gombák többféle módon ronthatják a gabona minőségét: csökkentik a csírázóképességet, szemmel látható elszíneződést, penészesedést okoznak, hatásukra dohos vagy savanyú szagú lesz a gabona, csökken a szemek szárazanyagtartalma, tápanyagtartalma, kémiai összetételük megváltozik, illetve mikotoxinnal szennyeződnek (Sauer et al., 1992). A mikotoxinok a penészgombák extracellulárisan kiválasztódó, többnyire másodlagos anyagcseretermékei (Kovács, 2001), amelyek a talajnövény-állat-ember táplálékláncba beépülve ma még pontosan fel nem becsülhető méretủ közegészségügyi veszély forrásai, és amelyek igen jelentős veszteségeket okoznak a hazai állattenyésztésnek. A ma már ismert toxikus gombametabolitok száma meghaladja az ezret, de újabb és újabb mikotoxinok felfedezése valószínűsíthető. Közülük mintegy száz mikotoxin káros hatásait bizonyították, de kiemelkedően nagy humán- és állategészségügyi jelentőséggel 15-20 mikotoxin rendelkezik. Köz- és állategészségügyi kedvezőtlen hatásaikat tekintve az aflatoxinoknak, a fuzárium toxinoknak, illetve egyes raktári penészgombák által termelt mikotoxinoknak van igen számottevő jelentősége (Rafai, 1999). A mikotoxin probléma jelentősége Magyarországon azért is elsőrendű fontosságú, mivel ezek a természetes toxinok a gabonafélékben találhatók (pl. búza, kukorica), melyek az ország vetésterületének tetemes hányadát foglalják el és egyrészt a lakosság fő táplálékául szolgálnak, másrészt a takarmányok fontos alapanyagát képezik (Kovács et al., 1998).

A fertőzés kialakulhat a szántóföldi járványok során, ebben a Fusarium nemzetség fajai jelentős 
szerepet játszanak. Simay (1992) 1986 és 1990 között penészes kukorica magvizsgálatánál is azt tapasztalta, hogy a leggyakrabban megfigyelt patogén szervezetek a Fusarium nemzetség tagjai, a $F$. avenaceum, $F$. culmorum, $F$. equiseti, $F$. graminearum, $F$. oxysporum, $F$. sacchari $v$. subglutinans, $F$. verticillioides voltak. Ezen a nemzetségen belül a fajok százalékos megoszlását vizsgálva kimutatható (Mesterházy és Vojtovics, 1977b; Mesterházy 1988a; cit Mesterházy, 1997), hogy országosan a $F$. moniliforme domináns $(41,7 \%)$, a $F$. graminearum $28,75 \%$-ot, a $F$. moniliforme var. subglutinans $6,85 \%$-ot, a $F$. culmorum $2,8 \%$-ot, a $F$. sporotrichioides 3,05\%-ot ért el további 10 faj kisebb arányú előfordulása mellett. Szécsi (1994) Magyarország harminc különböző kukorica termőhelyéről gyüjtött 45 növényminta feldolgozása során megállapította, hogy a Liseola szekcióba tartozó fuzárium izolátum 51,1\%-a $F$. moniliforme, $32,6 \%$-a $F$. subglutinans és $16,3 \%$-a $F$. proliferatum volt.

A Fusarium nemzetség által termelt toxinok közül hazánkban leggyakrabban a trichotecen toxinok (T-2, HT-2 toxin, deoxinivalenol, nivalenol, diacetoxyscirpenol, Fusarenon-X), valamint az ösztrogén hormonhatású zearalenon (F-2) fordul elö, de megkülönböztetett figyelmet érdemelnek az 1988ban felfedezett fumonizinek is (Kovács et al., 1997).

A gabona penészekkel való fertőződésének másik lehetséges útja a helytelen raktározás. A betakarítás után a raktári penészek, mint pl. a Penicillium és az Aspergillus fajok a tárolás során fokozatosan átveszik a szántóföldi penészek helyét és azoktól eltérő típusú toxinokat termelnek. Bár a szántóföldi penészek száma fokozatosan csökken a tárolás ideje alatt, ez nem zárja ki annak a lehetőségét, hogy megfelelő feltételek között továbbra is termelnek toxinokat (Scudamore, 1993). 1976 és 1983 között 1418 db raktározott kukoricaminta penészfertőzöttségének vizsgálatát végezte el Varga (1986). A tárolási időszak október 1-től következő év szeptember 30-ig tartott. A tárolás vége felé az összpenészszám abszolút értéke többszöröse volt a kiindulási értékeknek. A vizsgálat során 11 penészgomba nemzetséget sikerült izolálni és azonosítani. Ezek közül az Aspergillus és Penicillium nemzetség fajai fordultak elő leggyakrabban. Figyelemre méltó, hogy a szántóföldi flórához tartozó Fusarium fajok a tárolás minden időszakában megtalálhatók voltak viszonylag magas (8,6\%) százalékban. Hege (1998) tapasztalatai szerint fuzárium fertőzöttség mértéke még a $12-13 \%$ nedvességtartalmú búza esetében is növekedett. 1997-ben betakarított búzából augusztusban és szeptemberben még nem mutattak ki Fusariumot, de 1998. márciusában az egyes tételeinek fuzárium fertőzöttsége $0,4-0,6 \%$ körül alakult, július elejére pedig több tétel elérte a $0,8-1 \%$ os értéket.

Hart et al. (1982; cit. Wilson et al., 1992) 29 kukorica hibrid toxinvizsgálata során csak 7-ben tudta kimutatni a zearalenon, míg deoxinivalenonnal valamennyi minta szennyezett volt. Atlin et al. (1983; cit. Wilson et al., 1992) szintén találtak olyan hibrideket, amelyekben nem akkumulálódott zearalenon. Miller és Young (1985; cit. Wilson et al., 1992) őszi búzában 9,5 $\mu \mathrm{g} / \mathrm{g}$ DON-t és csak 0,06 $\mu \mathrm{g} / \mathrm{g}$ F-2-t, tavaszi búzában pedig 0,23-9,54 $\mu \mathrm{g} / \mathrm{g}$ DON-t találtak. Gross és Robb (1975; cit. Wilson et al., 1992) F. culmorum izolátumával fertőzték az árpát, de nem volt mérhetô zearalenon tartalma csak a 35\%-os nedvességtartalom mellett való tárolás után. A fent említett kísérletek eredményei alapján Wilson et al. (1992) arra következtetnek, hogy a takarmányoknak az a zearalenon mennyisége, ami gazdasági állatainkra veszélyes nem a szántóföldön, hanem a helytelen tárolás során termelödik.

Éppen ezért kutatómunkánk során célul tüztük ki az eltérő termőhelyi adottságú területekről származó, különböző körülmények között tárolt kukorica és őszi búza minták fuzárium fertőzöttségének, valamint toxin-szennyezettségének vizsgálatát. Arra kerestük a választ, hogy a termőhelyi adottságok (a talaj tulajdonságai, a hőmérséklet, a csapadék mennyisége és eloszlása), valamint a tárolási körülmények (hőmérséklet, nedvességtartalom, szemek állapota) hogyan befolyásolják a fent említett paramétereket, illetve hatásuk statisztikailag igazolható-e.

\section{ANYAG ÉS MÓDSZER}

A kísérletben szereplő kukoricamintákat 1997 és 1999 között az alábbi három talajtípuson termesztették: humuszos öntés talaj, típusos réti talaj, mészlepedékes csernozjom talaj. A termesztett hibridek 1997-ben a Norma, Colomba és Dekalb 527; 1998-ban az Mv 355, AW 043 és Dekalb 527; míg 1999-ben a Norma, AW 043 és Dekalb 493 voltak. Mindhárom évben a növényvédelem csak a gyomirtásra terjedt ki. A kukoricából a mintákat az MSZ 6978:1988 számú szabványban elöírtaknak megfelelően a betakarításkor vettük.

A kukorica mintavételével egyidejüleg az adott termőterület talajának felső $20 \quad \mathrm{~cm}$-es szántott rétegéből is vettünk mintákat, melyeknek meghatároztuk a főbb fizikai (leiszapolható rész \%, Arany-féle kötöttségi szám, nedvességtartalom), kémiai $\left(\mathrm{pH}_{\mathrm{H} 2 \mathrm{O}}, \mathrm{pH}_{\mathrm{KCl}}, \mathrm{CaCO}_{3}\right.$-tartalom, összes só\%, $\mathrm{Hu} \%$, szerves $\mathrm{C} \%$, összes $\mathrm{N} \%, \mathrm{NO}_{3}-\mathrm{N}$, AL-oldható foszfor és kálium tartalom) és mikrobiológiai (összcsíraszám, mikroszkopikus gombaszám, nitrifikáló és cellulózbontó baktériumok száma, biomassza-C, foszfatáz, ureáz, szacharáz és kataláz aktivitás) jellemzőit (Veres, 2001).

Betakarítást követően a mintáikat hat hónapig tároltuk háromféle hőmérsékleten úgy, hogy a minták felét kissé összetörtük, mellyel azt akartuk megvizsgálni, hogy sérült szemek nagyobb mértékben fertőződnek-e. A tárolási hőmérsékletek a következők voltak: $28^{\circ} \mathrm{C}, 18^{\circ} \mathrm{C}$ és $4^{\circ} \mathrm{C}$. Ezzel egyidejüleg a mintákat további két részre osztottuk és a minták felét az eredeti nedvességtartalom mellett, a másik felét 14\%-os nedvességtartalom mellett tároltuk. A minták tárolására jól záródó, ismert tömegü, előzőleg UV lámpa alatt sterilizált műanyag dobozokat használtunk, melyekbe mintegy 500-500 g kukorica került. 
Közvetlenül a betakarítás után, valamint a tárolás harmadik és hatodik hónapjában vizsgáltuk a Fusarium fertőzöttségét és a toxin szennyezettséget.

A Fusarium fertőzöttségének meghatározására 1997-ben a Papavizas-féle szelektív táptalajt, majd 1998-tól - a Fusarium fajok pontosabb azonosítása érdekében - a Togawa-féle szelektív táptalajt használtuk (Szécsi et al., 1998). A gombaszámot $10^{2}$ nagyságrendben $1 \mathrm{~g}$ gabonára vonatkoztatva adtuk meg.

Az egyes mintákból izolálható Fusarium fajok és más előforduló nemzetségek meghatározását fénymikroszkóp (900-szoros nagyítás mellett) segítségével Nelson et al. (1983), Domsch et al. (1980), valamint a Budapesti Kertészeti és Élelmiszeripari Egyetem Törzsgyüjteményéből származó Fusarium törzsek alapján végeztük.

A Fusarium fajok által termelt toxinok közül a gyakrabban előforduló, nagy gazdasági jelentőséggel bíró T-2, HT-2, DON, DAS és F-2 mennyiségi meghatározására törekedtünk. A mérések során - a nagy mintaszám miatt - egységes minta-előkészítést alkalmaztunk. Az univerzális minta-előkészítés alkalmasságának bizonyítására a Regionális Müszerközpontban - mely toxinvizsgálatokra is akkreditált laboratórium - visszanyerési vizsgálatokat végeztek el, ami alapján megállapították, hogy az általuk leírt módszer alkalmazható ezeknek a toxinoknak a vizsgálatkor. A minta-előkészítés az alábbiak szerint történt. $20 \mathrm{~g}$ őrölt mintát metanol és víz 1:1 arányú keverékével 1 órán át rázattuk, majd szürtük. Ezt követte egy kloroformos frakcionálás, amely után a mintákat nátrium-szulfáttal víztelenítettük, szürtük és bepároltuk. Közvetlenül a mérés előtt a mintákat acetonitrilben vettük fel. A méréseket AS-4000 automata mintaváltóval és L-4500 típusú diódasoros detektorral felszerelt Merck-Hitachi folyadékkromatográffal végeztük el, RP-18 $5 \mu \mathrm{m}(125 \times 4 \mathrm{~mm})$ oszlopon gradiens elúcióval. A készülék beállítási paraméterei:

\begin{tabular}{|c|c|c|c|}
\hline hullámhossztartomány: & \multicolumn{3}{|l|}{$190-300 \mathrm{~nm}$} \\
\hline fix hullámhosszak: & \multicolumn{3}{|c|}{195 nm (T-2, DAS) és } \\
\hline & \multicolumn{3}{|c|}{$236 \mathrm{~nm}(\mathrm{~F}-2, \mathrm{HT}-2, \mathrm{DON})$} \\
\hline gradiens elúció & \multicolumn{3}{|c|}{ A: acetonitril:víz $=5: 95$} \\
\hline eluensei: & \multicolumn{3}{|c|}{ B: acetonitril:víz $=41: 59$} \\
\hline \multirow[t]{5}{*}{ eluens összetétel: } & Idő (perc) & ACN:DV\% & $\mathrm{ACN}: \mathrm{DV} \%$ \\
\hline & 0 & 100 & 0 \\
\hline & 10 & 0 & 100 \\
\hline & 16 & 0 & 100 \\
\hline & 18 & 100 & 0 \\
\hline elválasztás időtartama: & 20 perc & & \\
\hline áramlási sebesség: & $1,5 \mathrm{ml} / \mathrm{perc}$ & & \\
\hline minta térfogata: & $20 \mu \mathrm{l}$ & & \\
\hline
\end{tabular}

A különböző mikotoxinok azonosítása és mennyiségi meghatározása kevert standard oldatok segítségével történt. A mikotoxinok kimutatási határértéke: T-2: $0,062 \mu \mathrm{g} / \mathrm{kg}, \mathrm{HT}-2: \mu \mathrm{g} / \mathrm{kg}, \mathrm{DON}$ : $0,080 \mu \mathrm{g} / \mathrm{kg}$, DAS $\mu \mathrm{g} / \mathrm{kg}, \mathrm{F}-2: 0,003 \mu \mathrm{g} / \mathrm{kg}$.

A mikrobiológiai és a toxinvizsgálatok eredményei, illetve az azokat meghatározó tényezők között a statisztikailag is igazolható összefüggéseket a MINITAB programcsomag segítségével igyekeztünk feltárni. A statisztikai módszerek közül a kovariancia-analízist végeztük el, mely során valamennyi független változót figyelembe véve értékeltük az egyes tényezők hatását az általunk tanulmányozott függő változókra. Arról, hogy ezeknek a tényezőknek a hatása mennyire szignifikáns a P-érték ad felvilágosítást. Mivel viszonylag kevés elemszámmal dolgoztunk, ezért a $\mathrm{P}=0,010$ alatti értékeket már elfogadtuk. Ez azt jelenti, hogy a kapott eredményünk több mint 90\%ban a befolyásoló tényezőnek és kevesebb mint 10\%ban a véletlennek köszönhető, vagyis szignifikánsnak mondható. A statisztikai elemzés során független változóként az évjárat, és a tárolási körülmények (hőmérséklet, nedvességtartalom, szemek sérülései) szerepeltek. Függő változóink voltak: a Fusarium fertőzöttség mértéke, az általunk mért egyes fuzárium toxinok mennyisége és az összes toxintartalom. Miután megbizonyosodtunk arról, hogy az adott tényező hatása szignifikáns, megvizsgáltuk a statisztikai program által kiszámított átlagértékek alapján, hogy az adott tényező mely értékéhez tartoztak nagyobb eredmények.

\section{EREDMÉNYEK}

A gabonaminták betakarításakor elvégzett vizsgálatok eredményeiből az alábbi következtetéseket vonhatjuk le.

A gabonák Fusarium fertőzöttségére vonatkozó eredményeink alátámasztják Mesterházy (1998) azon megállapítását, mely szerint a talaj típusa nem gyakorol jelentős hatást erre a paraméterre. Ezzel szemben a Fusarium fertőzöttséget és ezen keresztül a toxinszennyezettséget az évjárat, annak hőmérsékleti és csapadékviszonyai, nagymértékben befolyásolták. Kísérleti éveink közül kukorica kései fertőződése az 1998-as évben volt jelentős a csapadékos augusztus, szeptember hónapoknak köszönhetően.

A gombaflóra összetételére vonatkozóan számos neves szakember megállapításával összhangban (Szécsi, 1994; Mesterházy, 1997) elmondhatjuk, hogy Fusarium fajok közül a kukorica mintákban a $F$. moniliforme dominált.

A kukoricaminták toxinszennyezettsége 1999-ben volt a legerőteljesebb (1997-ben nem tudtunk toxint kimutatni, 1998-ban: T-2 tartalom 0,122 mg/kg, DON tartalom $0,100 \mathrm{mg} / \mathrm{kg}$ réti talajtípuson, 1999ben: T-2 tartalom: 0,462 humuszos öntés talajon és $5,241 \mathrm{mg} / \mathrm{kg}$ típusos réti talajon, F-2 tartalom: 0,189 mészlepedékes csernozjomon és $0,837 \mathrm{mg} / \mathrm{kg}$ típusos réti talajon), amikor is a hibridek virágzása idején a fertőződés és a toxinszintézis számára kedvezően alakult az időjárás.

A kukoricaminták hat hónapos tárolása alatt kapott eredmények alapján az alábbi következtetéseket vonhatjuk le.

$\mathrm{Az}$ általunk használt szelektív táptalajon izolálható mikroszkopikus gombák száma csökkent. Nagyobb gombaszámot kukorica esetében a szemek 
sérülései váltottak ki. A Fusarium fajok részaránya kisebb lett és egyre inkább a raktári penészként ismert Penicillium sp. vette át a domináns szerepet.

Annak ellenére, hogy a tárolás során Fusarium fajokat kisebb százalékban izoláltunk, a mintáinkban egyre több fuzárium toxin fordult elö, valamint a szennyezett minták száma és a toxinkoncentráció is növekedést mutatott. Eredményeink azt igazolják, hogy a fertőzöttség és a toxinszennyezettség között nincs szoros kapcsolat, illetve a szántóföldi penészek csökkenő száma nem zárja ki annak a lehetőségét, hogy megfelelő körülmények között továbbra is termeljenek toxinokat. A tároláskor biztosított magasabb hőmérséklet és nedvességtartalom, illetve a szemek sérülései több esetben pozitív hatást gyakoroltak a toxinkoncentrációra.

A statisztikai értékelés eredményeit - az ismétlések számát (n), a P-értékeket és az $\mathrm{SZD}_{5 \%}$ értékeket - az 1. és 2. táblázatokban tüntettük fel.

A befolyásoló tényezők hatása (P-érték) az eredeti nedvességi állapotú kukoricaminták vizsgált paramétereire

\begin{tabular}{|c|c|c|c|c|c|}
\hline Tényezők(1) & $\begin{array}{l}\text { Nedvesség- } \\
\text { tartalom(2) } \\
n=1\end{array}$ & $\begin{array}{l}\operatorname{Év}(3) \\
\mathrm{n}=18\end{array}$ & $\begin{array}{l}\text { Hömérséklet(4) } \\
\text { n=18 }\end{array}$ & $\begin{array}{c}\text { Szemek } \\
\text { állapota(5) } \\
n=27\end{array}$ & $\mathrm{SZD}_{5 \%}$ \\
\hline mikr. gombaszám $\left(\times 10^{2}\right)(7)$ & 0,440 & $\mathbf{0 , 0 3 6}$ & 0,533 & 0,900 & 18,43 \\
\hline $\mathrm{F}-2$ toxin $(\mathrm{mg} / \mathrm{kg})(8)$ & $\mathbf{0 , 0 3 1}$ & 0,000 & 0,361 & 0,890 & 1,21 \\
\hline $\mathrm{T}-2$ toxin $(\mathrm{mg} / \mathrm{kg})(9)$ & $\mathbf{0 , 0 3 0}$ & $\mathbf{0 , 0 0 0}$ & $\mathbf{0 , 0 3 3}$ & 0,611 & 0,72 \\
\hline HT-2 toxin $(\mathrm{mg} / \mathrm{kg})(10)$ & 0,733 & 0,006 & 0,927 & 0,792 & 0,29 \\
\hline DON toxin $(\mathrm{mg} / \mathrm{kg})(11)$ & 0,633 & 0,464 & 0,848 & $\mathbf{0 , 0 3 8}$ & 0,25 \\
\hline DAS toxin $(\mathrm{mg} / \mathrm{kg})(12)$ & 0,334 & 0,062 & 0,687 & 0,708 & 0,43 \\
\hline összes toxin $(\mathrm{mg} / \mathrm{kg})(13)$ & 0,024 & $\mathbf{0 , 0 0 0}$ & 0,197 & 0,769 & 1,65 \\
\hline
\end{tabular}

Table 1: The effect of factors (P-value) on the examined parameters of the corn stored at natural moisture content factors(1), moisture content(2), year(3), temperature(4), state of kernels(5), parameters(6), number of microscopic fungi(7), F-2 toxin content(8), T-2 toxin content(9), HT-2 toxin content(10), DON toxin content(11), DAS toxin content(12), total toxin content(13)

A befolyásoló tényezők hatása (P-érték) a nedvesített kukoricaminták vizsgált paramétereire

\begin{tabular}{|c|c|c|c|c|}
\hline Tényezők(1) & $\begin{array}{l}\operatorname{Év}(2) \\
\mathrm{n}=18\end{array}$ & $\begin{array}{c}\text { Hőmérséklet(3) } \\
n=18\end{array}$ & $\begin{array}{l}\text { Szemek állapota(4) } \\
\mathrm{n}=27\end{array}$ & $\mathrm{SZD}_{5 \%}$ \\
\hline mikr. gombaszám $\left(\times 10^{2}\right)(6)$ & 0,108 & 0,614 & 0,078 & 4,84 \\
\hline $\mathrm{F}-2$ toxin $(\mathrm{mg} / \mathrm{kg})(7)$ & 0,014 & 0,345 & 0,759 & 0,54 \\
\hline $\mathrm{T}-2$ toxin $(\mathrm{mg} / \mathrm{kg})(8)$ & 0,111 & 0,887 & 0,106 & 0,53 \\
\hline DON toxin $(\mathrm{mg} / \mathrm{kg})(9)$ & 0,564 & $\mathbf{0 , 0 7 3}$ & 0,854 & 0,06 \\
\hline DAS toxin $(\mathrm{mg} / \mathrm{kg})(10)$ & 0,310 & 0,969 & 0,477 & 0,05 \\
\hline összes toxin $(\mathrm{mg} / \mathrm{kg})(11)$ & 0,048 & 0,308 & 0,325 & 0,72 \\
\hline
\end{tabular}

Table 2: The effect of factors (P-value) on the examined parameters of the corn stored at $14 \%$ moisture content factors(1), year(2), temperature(3), state of kernels(4), parameters(5), number of microscopic fungi(6), F-2 toxin content(7), T-2 toxin content(8), DON toxin content(9), DAS toxin content(10), total toxin content(11)

Az eredeti nedvességi állapotú kukoricaminták vizsgált paramétereire (1. táblázat) szignifikáns hatást leginkább az évjárat és a szemek nedvességtartalma gyakorolt. Az évjáratnak a befolyásoló szerepét, a DON toxintartalomtól eltekintve, valamennyi vizsgált paraméterre vonatkozóan bizonyítottuk. Az 1997-es év az általunk használt szelektív táptalajon izolálható mikroszkopikus gombaszámban; az 1998-as év az F2, HT-2 és az összes toxintartalomban; az 1999-es év pedig a T-2 és a DAS koncentráció tekintetében eredményezett magasabb értékeket.

A szemek nedvességtartalma az F-2, T-2 és az összes toxintartalomra fejtett ki szignifikáns hatást.

A hőmérséklet hatását vizsgálva szignifikáns kapcsolatot csak a T-2 toxin esetében találtunk, $18^{\circ} \mathrm{C}$-on való tárolás mellett kaptunk nagyobb értéket.
A szemek sérüléseinek hatása a vizsgált mikrobiológiai és toxikológiai paraméterekre statisztikailag csak a DON toxin esetében igazolódott.

A kukoricamintáink felét 14\%-os nedvességtartalom mellett tároltuk, ezért azok vizsgálati eredményeinek statisztikai feldolgozásakor független, állandó változóként már csak az évjárat, a hőmérséklet és a szemek állapota szerepelt.

Megállapítottuk, hogy ezeknél a mintáknál (2. táblázat) az évjáratnak kevesebb paraméterre - F-2 és az összes toxintartalom - volt szignifikáns hatása. Ez talán magyarázható azzal, hogy az évjárat hatását esetünkben elsősorban az határozza meg, hogy adott évben hogyan alakulnak a hőmérsékleti és csapadékviszonyok, illetve ezeken keresztül a szemek nedvességtartalma. Így azáltal, hogy mindhárom évben azonos nedvességtartalmat 
biztosítottunk, csökkentettük az évjárat esetleges befolyásoló szerepét.

Ha azonban megvizsgáljuk, hogy az egyes években az évjárat hatására hogyan változtak a fent említetett paraméterek, akkor ugyanazt a tendenciát tapasztaljuk, mint az eredeti nedvességi állapotú kukoricaminták esetében. Vagyis az F-2 és az összes toxintartalom is 1998-ban volt a legnagyobb.

Eredményeink alapján megállapíthatjuk, hogy a tárolási hömérséklet csak a DON toxin mennyiségére hatott szignifikánsan. Ennek a toxinnak a szintézise $28^{\circ} \mathrm{C}$-on való tárolás mellett volt a legerőteljesebb.

A szemek általunk előidézett sérülései a toxinok szintézisét nem, viszont a mikroszkopikus gombaszámot szignifikánsan befolyásolta. A sérült szemeket tartalmazó mintákban nagyobb volt ezeknek a mikroorganizmusoknak a mennyisége.

A tárolási körülmények hatását elemezve, összefoglalóan elmondhatjuk, hogy a magasabb hőmérséklet és nedvességtartalom, illetve a szemek sérülései kedvezőtlenül befolyásolták a tárolt kukoricaminták mikrobiológiai és toxikológiai tulajdonságait, és ez a hatásuk statisztikailag is igazolható. Éppen ezért ha a szántóföldön megtermelt kedvező tulajdonságokkal rendelkező gabonát a későbbiekben hasonló minőségben kívánjuk felhasználni, nagy hangsúlyt kell fektetni a tárolás előtti terménykezelésre ( $\mathrm{pl}$. sérült és zsugorodott szemek rostával való elválasztása, a termény nedvességtartalmának szárítással való csökkentése) és a szakszerü tárolásra. Ez utóbbi ideje alatt folyamatosan ellenőrizni kell a termény minőségét, illetve az azt befolyásoló faktorokat. Szükség esetén célszerü a terményt átforgatni, szellőztetni, illetve vegyszeres úton védekezni a mennyiséget és minőséget csökkentő kórokozók, kártevők ellen.

\section{IRODALOM}

Domsch, K. H.-Gams, W.-Anderson, T. (1980): Compendium of soil fungi. Academic Press, London, 1-859.

Hege O. (1998). Milyen az idei gabona fertőzöttsége? Magyar Mezőgazdaság, 14

Kovács F. (2001): Penészgombák-mikotoxinok. In: Penészgombák-mikotoxinok a táplálékláncban (szerk. Kovács F.). MTA Agrártudományok Osztálya, Budapest, 13-20.

Kovács F.-Banczerowski J. (1997): Környezetszennyező kemikáliák és természetes toxinok. Magyar Tudomány, 8. 897-909.

Kovács F.-Banczerowski J-né-Zomborszkyné K. M.-Fazekas B. (1998): Életminőség és a mikotoxinok egészségügyi vonatkozásai (1.). Állattenyésztés és Takarmányozás, 47. 5. 385-402.

Mesterházy Á. (1997): A szántóföldi növények mikrobiális patogén szennyeződésének csökkentése, humán egészségügyi minőségének javítása. AGRO 21 füzetek, 14. 91-130.

Mesterházy Á. (1998): A penészgombák és a mikotoxinok vizsgálata. In.: Mikotoxinok a táplálékláncban (szerk. Kovács F.). MTA Agrártudományok Osztálya, Budapest, 13-77.

Nelson, P. E.-Toussoun, T. A.-Marasas, W. F. O. (1983): Fusarium species. The Pennsylvanian State University Press, USA. 1193.

Rafai P. (1999): A fuzariotoxinok hatása a sertés termelésére és egészségére. Állattenyésztés és Takarmányozás, 48. 2. 253264

Sauer, D. B.-Meronuck, R. A.-Christensen, C. M. (1992):
Microflora. Storage of Cereal Grains and Their Products (ed. Sauer). American Association of Cereal Chemists, Inc. St. Paul, Minnesota, USA. 313-340.

Scudamore, K. A. (1993): Occurence and significance of mycotoxin in cereals grown and stored in the United Kingdom. Aspects of Applied Biology 36. 1993. Cereal Quality III. 361-373.

Simay E. I. (1992): Magvizsgálatok eredményei. XXII. - Kukorica penészes magvain megfigyelt gombák. Növényvédelem, 28. 7-8. 285-289.

Szécsi Á. (1994): A Liseola szekcióba tartozó Fusariumok előfordulása hazai kukoricakultúrákban 1991. és 1992. években. Növényvédelem, 30. 7. 313-317.

Szécsi Á.-Mesterházy Á. (1998): Szelektív táptalaj alkalmazása Fusariumok izolálására és azonosítására gabona- és kukoricaszemekből. Növényvédelem, 34. 2. 61-66.

Varga I. (1986): A tárolt kukorica penészfertőzöttségének vizsgálata. Növényvédelem, 22. 11. 497-501.

Veres E. (2001): Termőhelyi adottságok és tárolási körülmények hatása a kukorica és az öszi búza Fusarium toxin szennyezettségére. PhD értekezés, 36-38.

Wilson, D. M.-Abramson, D. (1992): Mycotoxins. Storage of Cereal Grains and Their Products (ed. Sauer). American Association of Cereal Chemists, Inc. St. Paul, Minnesota, USA. 341-391.

MSZ 6978/1988 (1988): Mintavétel a takarmányok mikrobiológiai vizsgálatához. 